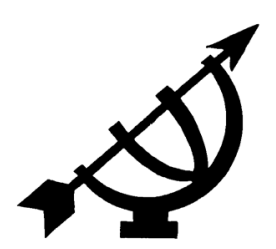

\title{
Institutional identity: a possible solution to the religion in/and education quandary
}

\author{
J.L. van der Walt \\ Faculty of Education Sciences \\ Potchefstroom Campus \\ North-West University \\ POTCHEFSTROOM \\ E-mail: hannesv290@gmail.com
}

\begin{abstract}
Institutional identity: a possible solution to the religion in/and education quandary

The problem of religion in/and education is a worldwide one for education policy-makers - even in the most homogeneous populations. Several strategies have been developed for coping with this problem, but they tend to fall short in terms of finding equilibrium on the universal-particularity continuum. There is a way for attaining the desired equilibrium, namely to take account of the institutional identity of each individual school, and to allow each school community the freedom to choose the type of religion education that would be most suitable to its particular needs and circumstances.
\end{abstract}

\section{Opsomming}

Institusionele identiteit: 'n moontlike oplossing vir die godsdiens in/en onderwys-dilemma

Wêreldwyd het onderwysbeleidmakers te doen met die vraagstuk van godsdiens in/en die onderwys - selfs in die mees homogene samelewings. Verskeie strategieë is al in die verlede bedink om die probleem die hoof te bied, maar hulle skiet almal te kort in terme daarvan om 'n ewewig op die universeelpartikulier-kontinuum te vind. Daar is egter nog 'n manier om die gewenste balans op die kontinuum te vind, naamlik deur met die gedagte van die institusionele identiteit van elke skool te werk, en om op grond daarvan elke skoolgemeenskap die vryheid te gun om die soort godsdiensonderwys te kies wat die 
beste sal voldoen aan sy eie besondere behoeftes en omstandighede.

\section{The problem}

All systems of education find themselves confronted with the problem of whether or not to offer confessional religious education to learners in public or state-funded schools, or only education about religion/the different world religions. A survey of the World Factbook (2008; cf. also Anon., 2002; Vilar, 2005; Goodstein, 2005) shows that even the most religiously homogeneous countries have to deal with the problem of religious diversity (cf. Hagesaeter \& Sandsmark, 2006:277). How can policy-makers cope with religious diversity in a particular school or classroom without causing tension or violating citizens' fundamental rights? This problem statement can be broken down into a host of questions.

Can one overcome the problem with only one religion subject in schools? Can the solution be found in teaching only sets of religious dogmas or intellectual facts, shorn of all religious cult or activities (i.e. not as personal, confessional faith or sets of beliefs)? Should one attempt to smooth over the differences and concentrate only on those features shared in some or other way by all religions in order to promote tolerance, deeper understanding of others and their differences? Or does one rather accentuate the differences in the expectation that once learners gain insight into the uniqueness of their own religion/faith, they will develop greater understanding and tolerance of others and their particular religious uniqueness, and in doing so learn to enjoy the diversity (Jansen, 2008:16)? Why, in spite of all the efforts of education authorities (departments of education/administrations) all over the world to promote understanding, tolerance and peaceful coexistence, are we still confronted with religious exclusivism, disrespect, stereotyping and persecution, with xenophobia and contempt for others based on religious and other cultural differences, with religious discrimination, prejudice, intolerance, misunderstandings and violence, and with propaganda against other religions/faiths?

Should we allow confessional religious education in state-funded schools or not? Does the policy of exempting dissenting learners from confessional, sectarian education not constitute a violation of their constitutional (human) rights? Should we allow religious values and sentiments to influence public life via the public school? Does the total abolishment of religion from school premises not constitute a violation of parents' rights to have their children taught in the faith 
of their choice? Does abolishment not mean encroachment by the state on the sovereign competency sphere of the school? Does this not lead to dualisms, such as private-public, home-school, sacredsecular, confessional-secular? Can such dualisms be ontologically defended?

Should we rather look for the solution in comparative, interfaith, inter- or multi-religion education? Is there any justification for only teaching (comparative, etc.) religion education and allowing religious observances in public schools, but not religious (confessional, sectarian) education? Does such an artificial distinction not lead to religious schizophrenia in learners? Or should we look at international organisations and their charters to come up with a solution, as suggested by Høstmaelingen (2005:409)?

Is secularism (humanism) indeed the best approach to the problem? Can we have faith in authorities who offer toleration, and argue that they do not promote secularism or a secular state, because they do not support any hostility between state and church, between schooling/teaching and religion (provided that only religion education, i.e. education about religion(s), is included in the curriculum), and do not use the pulpit or church (etc.) funds to support political candidates or promote values that would affect the state or government? Are sectarian religious influences indeed harmful to public life, as Rorty (2003:141) averred?

After presenting a discussion of some key concepts, several strategies for dealing with the problem will be discussed. In doing so, several sets of evidence, including expert opinions, legal judgements and empirical findings will be offered. It will be contended that none of the current solutions to the problem can be effective, because of their inherent failure to meet the requirements of a basic ontological law, namely the need to attain balance on the universalparticular continuum. After discussing this shortcoming, the article will be concluded by offering an alternative approach that revolves around the concept of the institutional identity of schools.

\section{Some key concepts}

Along with the compilers of the South African National Policy on Religion and Education (2003), I distinguish between religious instruction, religion education and religious observances. Religious instruction refers to education for the purpose of inculcating a particular faith or sectarian religious tenets in learners (RSA, 2003: section 54). This is a confessional (sectarian, denominational) form of 
education. Because of its particularity, it excludes the teaching of any other religion or faith. Religion education refers to the teaching of religion as a phenomenon. This is a non-confessional, scientific, academic, supposedly neutral, generic and general approach that focuses on the universal traits that all religions supposedly share (cf. Abdool et al., 2007:545-547 for a discussion of such traits; cf. also RSA, 2003:section $17 \mathrm{ff}$.). Religious observances refers to the cultic or ceremonial practices or services associated with the different religions observed by the learners in a school such as prayer, singing of sacred songs, recitals and reading from holy Scriptures (RSA, 2003: section 58 ff.).

Religious institutions in this discussion refers to institutions such as churches, mosques, synagogues, temples, shrines; special places for worshipping a deity or for cultic practices. Occasionally references to "churches (etc.)" will be used as a correlative to "religious institutions". The author finds Rorty's (2003:141) term "ecclesiastical organizations" restrictive, since ecclesia refers to the Christian church, and not to other religious institutions such as the mosque or the synagogue.

Secularism refers to the view that religion, religious values and considerations and also religious institutions should play no role in public affairs (Van der Walt, 2007:228), and that the latter should not strive to acquire economic or political clout (Rorty, 2003:141). This is not an imaginary problem as can be seen in the Irish Republic up to the 1970s where the influence of the Catholic Church was "pervasive on all levels of thinking" (English, 2007:323).

Secular humanism extends the secularist view. It holds that in a secular state or society the interests of human beings, the citizens, should be pivotal and not those of a divine or transcendent force. Many secular humanists adhere to the utilitarian, pragmatic and libertarian Benthamite principle of the maximum feasible benefit for the maximum possible number rather than to any religious principle (English, 2007:136; Rorty, 2003:148). If religion should disappear, as Rorty (2003:142) hopes will happen, the gap will be filled by "a(n) increased sense of participation in the advance of humanity ... toward the fulfilment of social ideals" and the attainment of social justice. Nothing, not even religion or quotes from the Bible or the Q'uran, should stand in the way of the utilitarian promotion of public interests (Rorty, 2003:143 ff.). In brief, says Rorty (2003:144), "if we secular humanists have our way, the liberal democracies will eventually mutate into societies whose most sacred texts were written by John Stuart Mill". Positions taken in public life should be 
substantiated with good reasons and not merely based on appeal to some or other authority, Scriptural or otherwise (Rorty, 2003:147, 149; cf. also Woolfenden, 2008:5).

Institutional identity refers to how stakeholders in a school understand and describe the particular institutional life-conceptual, philosophical and/or religious character of their school. In the last part of this article, institutional identity will be connected to the ontological problem of equilibrium-seeking on the universal-particular continuum as well as to a possible solution to the religion in/and education problem.

Fukuyama (1996:26-27) provides us with a pithy definition of social capital: it is the accumulated social wealth that arises from the prevalence of trust in a society or certain parts of it. It differs from other forms of capital in that it is usually created and transmitted through cultural mechanisms like religion, tradition, or historical habit. Acquisition of social capital requires habituation to the moral norms of a community (cf. also Van der Walt, 2009).

Having set the stage for a discussion of the problem of religion in education, I shall now proceed to a discussion of the forms that the so-called religion in/and education problem can assume.

\section{The different forms of the religion in/and education problem}

The first and most obvious form in which the problem manifests itself, is the choice between offering or allowing religious instruction in a state or public school, and offering or allowing only religion education. Put differently: should a state or publicly funded school offer or allow education of a particular religion, or only teaching about religion(s) in general? Those in favour of the first view argue that the anthropological integrity of learners should not be compromised in any way, that there should be no rupture in a learner's religious or faith education. Those in favour of the second view use the secularist argument that states and institutions such as publicly funded schools may not be abused for the promotion of confessional, sectarian or private values. The promotion of religious values is the task of the parental home and/or religious institution.

The problem as outlined above forms part of a larger problem, namely the conservative right versus the liberal/secular/atheist left controversy (cf. The Pew Forum, 2008). This is sometimes referred to as the "wall of separation between state and religious institutions" 
controversy. Williams (2005) referred to this thorny issue as the "First Amendment ban on the establishment of religion" in the public or state sphere. The problem revolves around the relationship between religious institutions and the state (government), and the degree to which the sectarian views of different religious institutions should be allowed to influence the public sphere of the state and its affairs. Secularists regard education as essential to the forging of the good national citizen. If a nation has to be built across confessional divides, then denominationally divided education would be disastrous for those who seek to produce a shared communal identity and national purpose (English, 2007:149). Rorty was a famous exponent of this position. In Rorty's (2003:141) opinion, the exclusion of religious convictions from the public square "was part of a reasonable compromise between secular democratic governments and ecclesiastical organizations". Rorty (2003:148) illustrates the "wall of separation" philosophy with reference to the attitude of John F. Kennedy. While remaining a professing churchgoing Catholic in his private life, Kennedy "had no intention of taking ecclesiastical authority seriously when exercising the functions of office". As can be expected, this approach has been decried by its opponents as "godless" (English, 2007:150).

The problem of religion in/and education also takes the form of a tension between the private and the public lives of citizens. Some regard a separation of these two domains as advisable for bridging the gaps in the cultural (including religious) diversity in public life. Their opponents reject this approach based on the argument that such separation is nothing less than a form of anthropological dualism. It compromises the inherent unity and integrity of learners as human beings.

The problem can also take the form of a tension between the fundamental right of parents as the primary educators of their children to inculcate in them a particular religion/faith (Høstmaelingen, 2005:408; Hagesaether \& Sandsmark, 2006:284) and to expect the school to do the same, and the right of the school as a public institution not to teach a particular form of religion or faith, but rather to inform its future citizens about all the religions prevalent in their particular community or state. This is the in loco parentis problem. Some interpret this phrase to mean literally that the school should take the place of the parents, to continue the work of the parental home, also as far as religious education is concerned. Others understand the phrase only to mean that school teachers should care for the children as if they were the parents of the child. 
However, a school or the teachers can never completely replace the parents (cf. Van der Walt \& Oosthuizen, 1998 for an analysis of this phrase).

The problem is also connected to the fundamental rights of citizens. Does a citizen's constitutional right to freedom of speech, religion, opinion and association also extend to insistence on religious instruction, to education in a particular faith, in public schools? Or would the inclusion of such a subject constitute a violation of the fundamental rights of others? Hagesaether and Sandmark's (2006) recent empirical study covers both sides of this problem.

In their study in Norway in 2000, 31\% of the parents interviewed (all of them churchgoing Christians) said that they were not happy with the general religion education course offered in the public schools. They wanted the school to convey to the children that what they learnt at home was right and true. The more religiously active parents were more insistent than the passive ones that the school should confirm the religion taught at home (Hagesaether \& Sandsmark, 2006:279, 282). In 2002 the Norwegian Parliament introduced a compulsory subject to give learners a common basis of knowledge, culture and values and to promote understanding, respect and dialogue between adherents of different faiths and worldviews. The Parliament also withdrew the right of learners to be exempt from the subject, a step which elicited questions about whether the fundamental rights of parents and learners (parental say and freedom of thought and religion) were not being violated (Hagesaether \& Sandsmark, 2006:283). Some of the parents who objected to having been denied the right to withdraw, took their case to court. After having lost their case in Norway, the parents of four pupils appealed to the United Nations' Human Rights Committee in 2003. In 2004 the Commission passed a verdict in favour of the appellants, in the process referring to Article 18.4 of the United Nations International Covenant on Civil and Political Rights, which "permits public school instruction in subjects such as the general history of religions and ethics if it is given in a neutral and objective way" and that

... public education that includes instruction in a particular religion or belief is inconsistent with article 18, paragraph 4, unless provision is made for non-discriminatory exemptions or alternatives that would accommodate the wishes of parents or guardians.

As a result of this verdict, the Norwegian Education Act was amended in 2005 to include the right of withdrawal from classes in religion 
education and to receive alternative teaching (Hagesaether \& Sandsmark, 2006:284; cf. also Høstmaelingen, 2005 for a discussion of the Leirvåg et al $v$. Norway case of 3 November 2004).

Others argue that confessional religious education in a public or state school would constitute a violation of the rights of learners not belonging to that particular faith, because of its restrictive and exclusive nature. There are compelling reasons for the claim that every learner should know and understand the cultural and religious heritage of their nation and particular community. Children, therefore, have the right to a religion education that would develop their understanding and respect for both their own religion as well as those of others, and thus become prepared for responsible citizenship. According to Hagesaether and Sandsmark (2006:285), "it is hardly possible to use human rights arguments against such knowledge and understanding".

As both Hagesaether and Sandsmark (2006), and Høstmaelingen (2005) conclude, it is difficult to resolve this problem in terms of human rights theory. The problem of conflicting interests can hardly be eradicated by following this route.

The problem also sometimes takes the form of a conflation of religious institutional ideals and school education. This approach finds expression in church (etc.) schools. The phenomenon of church (etc.) schools sits awkwardly with the principle of sphere sovereignty: the church (etc.) encroaching on the sovereignty of the school as a separate and independent societal relationship.

Some base their plea for only providing religion education in schools on the argument that "it would be healthy if religious people regarded all the major religions as manifestations of one God". This will in their opinion facilitate the teaching of tolerance which is so vital for the future of mankind (Martin, 2007:390; cf. also the United Nations' Earth Charter, 2000). Their opponents reject this view, because they believe that only their religion has the one true God.

\section{Why have (most of) these strategies failed?}

Why is it so difficult to find an acceptable solution? In my opinion, the failure of current strategies can be ascribed to their essentially 
incorrect approach to the universal-particular1 continuum (cf. Smollett, 2002). Those who favour the exclusion of all forms of religion education from schools, because they feel that to do so would be advantageous for a common citizenship, as well as those who favour only the admission of religion education and religious observances, seem to drift towards the universal pole of the continuum. Their theories tend to emphasise the generic, common, universal aspects of society as well as the generic, common and universal aspects of religion as a phenomenon.

On the other hand, those who argue for the inclusion of religious instruction (education in/of a particular religion), even to the extent of excluding all other forms of religion as well as religion education, seem to drift towards the opposite extreme of the continuum, i.e. the particular. In renouncing the teaching of universal, general, generic religion education, they find themselves in the company of philosophers who question the existence of universals.

Some argue, for instance, that granting ontological status to universals (in this case, the universal characteristics that all religions supposedly share) is to resort to Platonic realism. Platonic realism holds that universals exist in a supra-natural idea(I) world, in a Platonic "heaven" separate from our spatiotemporal world, independent of particulars (universalia ante rem). Universals may instantiate particulars, or they may not (Smollett, 2002). Universalism should be rejected, they say, in favour of empiricism, pragmatism and utilitarianism. There is no need for Platonic universals and rationalism as foundations (normative or foundational resources) for our social decisions, such as whether religion should be taught in schools or not. Decisions should rather be based on empirical, non-metaphysical, common sense, pragmatic, utilitarian arguments and experimental open-mindedness (cf. Rorty, 2000:79; 2004:54). Rortyan pragmatists and utilitarians therefore abandon any striving after certain knowledge, grounded facts and objective truth, and accept that concepts of truth and rationality do not reveal participation in universal human nature, but rather in association with a specific community which is the heir of a specific tradition. Instead of re-

1 The universal pole finds expression in terms such as unity, commonality, generic, general, global, uniformity, a single idea applicable to all instances in the same way, a general idea, and the particular pole in terms such as diversity, contingency, locality, specificity, individuality, difference(s), variation, variants, variety, relativism, thing in itself, a thing apart from others (cf. also Van Niekerk, 2005:28-29; Woolfenden, 2008; Knight, 2008; Jansen, 2008). 
sorting to universal notions of truth, the pragmatist does what is deemed apposite in the given circumstances in a particular community (Van Niekerk, 2005:22). This form of pragmatism should also apply in policy making with respect to religion in/and schools. The important thing to note here is the preference for the particular pole of the continuum - to the detriment of the universal.

Nominalists likewise, have no need for universals. Nominalism does not depend on whether a thing that is referred to is instantiable or not (Smollett, 2002). What we refer to as a "universal" is merely the nomen (name) of something that actually exists. Universals, therefore, have no ontic status; they are just the names or labels given to describe and categorise collections of particulars. In terms of this argument, the universal known as "religion" is just a name tag for a category of phenomena. Conceptualists go one step further than nominalists. They hold that universals are not only name tags, but also that they exist only in the minds of people (MacLeod \& Rubenstein, 2006) (universalia post rem).

Aristotelian realists recognise the existence of universals, but believe that they exist only in the one-realm spatiotemporal world of particulars and not in a separate metaphysical Platonic "heaven" (Smollett, 2002; Woolfenden, 2008:3) (universalia in re). "Whiteness", therefore, exists only in a particular thing, such as a horse. A universal of which a practical instance cannot be provided, an uninstantiated universal, therefore, does not exist or must be fictitious or hypothetical (Woolfenden, 2008:5, 6). Since no actual instance of a unicorn has been discovered so far, unicorns probably do not exist. By the same token, if a religious tenet cannot be instantiated in the form of a particular precept or dogma, it can be assumed not to exist. It therefore makes little sense to teach universal religious tenets to children. Religious tenets only come to life once they are actually instantiated. In terms of this argument, learners should be taught the tenets of an actual religion, in its confessional, sectarian form.

This particularist argument can be summarily countered with the universalist retort that to teach all the different sectarian forms of religion in schools would be impracticable, that it would be more practical to teach only the "universal form", instantiable or not. It would be impractical to provide several teachers in each school, one for each of the religions represented in the learner population. One teacher will not be up to the task of teaching all the religions, mainly because of him-/herself belonging to a particular religion and 
therefore likely to be biased towards learners adhering to other religions.

Is there a way out of this quandary?

\section{A possible way out of the religion in/and education quandary}

My thesis is that it is difficult if not quite impossible for the policymakers of an entire school system to find the necessary equilibrium on the above-mentioned continuum on behalf of each individual school in the system. A glance at the work of MacLeod and Rubenstein (2006), Brown (quoted in Woolfenden, 2008) and Thiessen (quoted in Jansen, 2008) shows that this is a notoriously difficult task that has been keeping philosophers and educationists busy for many centuries.

As we have seen, tendencies of drifting to either of the extremities of the universal-particular continuum do not provide a solution. The shortcoming so far, as I see it, has been that policy-makers have been focusing on religion and on the school system rather than on the particular school in which religion has to be taught or not. There is just no way that national, state or provincial policy-makers can formulate policy about the teaching of religion that would satisfy the needs of each and every local school community, including the parents and the learners. Policy-makers, therefore, need to shift their attention to individual local schools and their institutional identities.

The key to the problem can be found in what I, in following Bakker (2002:101), De Wolff et al. (2003:208; 2002:239-240), shall refer to as the institutional identity of a school. This term is broadly synonymous with institutional ethos. Ethos, according to Sinclair (1999: 489 ), refers to the distinctive character, spirit and attitudes of a particular group or organisation, in this case a school (community). It embraces the philosophy, life-view and value system of the particular school (Plug et al., 2007:98) as well as the concomitant set of beliefs, ideas and conceptions about social behaviour and relationships of the institution or group (Procter, 2002:470).

Institutional identity refers to those dynamic characteristics which make a school what it is at a given point in time. It refers to those typical characteristics or features that make this particular school unique, that the stakeholders in the school share with one another (also as a collective) and that endure for a time. According to Bakker and Rigg (2004:14), this definition draws our attention to an actual 
school: this specific school (not schools in general), with these teachers and learners in this specific context. Extra-school conditions and contexts, for instance the Christian-reformational school tradition, also impact on a school's institutional identity. Identity is contingent on the particularities of local time and place. The important thing to note is, however, that each particular school shapes such ideas and influences to form its own unique institutional identity. In doing this, we take the particular pole of the continuum as point of departure.

In contrast to the Dutch education system where a group of schools with the same or similar life-conceptual institutional identity clusters together in a so-called pillar (Sturm et al., 1998), policy-makers/the education system should allow each and every school, whether state/public or private/independent, the freedom of determining for itself its own institutional identity. All the stakeholders in a particular school should convene and decide for themselves what the identity of their particular school in fact is, or think it should be.

The next step is for them to decide where they wish to position their school on the universal-particular continuum. This, in my opinion is the only way of ensuring true equilibrium.

The final step is for the school (community) to formulate its institutional identity in its vision and mission statement and to proclaim its identity to the surrounding community. This will enable parents and learners to decide whether they can or should associate themselves with the school or not.

Why is this an appropriate solution to the problem of religion in/and education?

In the first place, it is democracy at work where it matters most - at the local level. Only the stakeholders actually involved in a particular school determine its institutional identity. Formulation of the institutional identity is an expression of their democratic will. Because all schools enjoy exactly the same freedom to determine their respective institutional identities and all are equally and equitably financed by the state, they can all contribute on an even footing to the human and social capital of their particular communities, and also of the state.

Secondly, involving only direct stakeholders in the local life of a school in determining the school's institutional identity would prevent the state, the churches (etc.) and other institutions from infringing on 
the sphere sovereignty of the school. No other societal relationship can be as responsive to the religious (education) needs of a school as its own stakeholders. The stake of the state/education department will be restricted to funding and determining the formal parameters for schools and schooling (Flitner, 2006:184). Governments sometimes contend that their financing of a school entitles them to a say in determining the school's institutional identity (cf. Samsom, 1981). However, state/government say in this impinges upon the sphere sovereignty of the school as a societal relationship that is clearly distinguishable and in principle independent from the state or government. Flitner (2006:181) correctly speaks of the school as "eine eigene Einrichtung", i.e. an organisation or societal relationship that is independent from both family home and the state, despite their having stakes in the school.

The proposed approach furthermore amounts to a system of "private" or "independent" schools within the state-funded system. All schools in the system are equitably funded by the state, on condition that they meet certain requirements, one of which should be that a school must have proclaimed its institutional identity. Put differently, each school can express its uniqueness (which is a reference to the particular pole of the continuum) and also the extent to which it shares its vision and mission with other schools (the universal pole).

Private schools will become obsolete. In the proposed system, all schools will be state schools, funded with public tax money (the universal pole). They will at the same time all be private or independent in the sense of each having the freedom to determine their own unique institutional identities (the particular pole).

Another problem will have been circumvented: all three forms of educating (about) religion (i.e. confessional religious instruction, academic religion education and religious observances) can in principle find a place in each school, because the religion(s) selected by the school administrators, the parents and the learners will be in line with the school's proclaimed institutional identity. This will eliminate all current threats to the ontological and anthropological integrity of the schools and the learners.

The main advantage of this proposal is that each school would enjoy the liberty of deciding for itself whether it wishes to gravitate towards the universal pole, to the opposite extreme or to the more balanced middle of the continuum. A school's policies will be dictated by its local circumstances, including the religious composition of the particular community. 
The proposed system will furthermore allow parents and learners to join those schools of which the identities resonate best with their own religious and faith convictions. Where the choice of schools is inadequate, as in small communities, parents could send their children to neighbouring schools (with state aid for transport and/or accommodation). The obvious solution for a small community, however, would be to define the institutional identity of the school in such terms that all the religions prevalent in that community can be accommodated (a strategy supported by Hagesaether \& Sandsmark, 2006:286, and mentioned as a route for states to take by Høstmaelingen, 2005:407). This might of course also mean a decision that all forms of education about religion should be avoided, or that all of them should be offered in the school, among others, by providing a religious education teacher for each of the religious denominations (with state and/or parental subsidies which, as argued above, would not be the most practical solution). This problem would understandably be non-existent in large communities; parents and learners will have a sufficiently wide choice of schools.

\section{Concluding remark}

The proposed system of having private or independent schools within the state or public funded system meets all the societal relationship requirements, such as sphere sovereignty, as well as important ontological and anthropological requirements such as striking a balance on the universal-particular continuum. Implementation of the new system requires from policy-makers to henceforth shift their focus from guidelines for the entire education system to the needs and requirements of each individual school in the system.

\section{List of references}

ABDOOL, A., POTGIETER, F.J., VAN DER WALT, J.L. \& WOLHUTER, C.C. 2007. Inter-religious dialogue in schools: a pedagogical and civic unavoidability. HTS theological studies, 63(2):543-560.

ANON. 2002. Around the world. Education journal, 63:19.

BAKKER, C. 2002. Hoe geef je vorm aan de indentiteit van de school? (In Miedema, S. \& Vroom, H. 2002. Alle onderwijs bijzonder. Zoetermeer: Meinema. p. 97-124.)

BAKKER, C. \& RIGG, E. 2004. De persoon van de leerkracht. Zoetermeer: Meinema.

DE WOLFF, A.J.C., DE RUYTER, D. \& MIEDEMA, S. 2003. Being a Christian school in the Netherlands: an analysis of "identity" conceptions and their practical implications. Journal of beliefs \& values, 24(2):207-217. 
DE WOLFF, A.J.C., MIEDEMA, S. \& DE RUYTER, D. 2002. Identity of a Christian school: conceptions and practical significance. A reconstructive comparison. Education review, 54(3):239-247.

ENGLISH, R. 2007. Irish freedom. London: Macmillan.

FLITNER, A. 2006. Schule. (In Krüger, H-H. \& Helsper, W., eds. Einführung in Grundbegriffe und Grundfragen der Erziehungswissenschaft. Opladen: Barbara Budrich. S. 181-190.)

FUKUYAMA, F. 1996. Trust: the social virtues and the creation of prosperity. New York: Free Press.

GOODSTEIN, L. 2005. From mosque to steeple, faith rises. The New York times (articles selected for Sunday times): 1, 4, 23 Jan.

HAGESAETHER, G. \& SANDSMARK, S. 2006. Compulsory education in religion - the Norwegian case: an empirical evaluation of RE in Norwegian schools, with a focus on human rights. British journal of religious education, 28(3):275-287.

HØSTMÆELINGEN, N. 2005. Mandatory religious education that builds tolerance: lessons to be learned from Norway? The international journal of children's rights, 13:403-412.

JANSEN, L. 2008. Het verband tussen verbondenheid, verscheidenheid en verdraagzaamheid: onderwijsfilosofische concepties van een Canadees, Elmer J. Thiessen. DRS magazine, 36(1):14-16, Jan.

KNIGHT, K. 2008. Universals. Catholic Encyclopedia. http://www.newadvent. org/cathen/15182a.htm Date of access: 26 Dec. 2008.

MACLEOD, M.C. \& RUBENSTEIN, E.M. 2006. Universals. The internet encyclopedia of philosophy. http://www.iep.utm.edu/u/erubenst@iup. edu?subject=Your Universals Article Indiana University of Pennsylvania. http://www.iep.utm.edu/u/universa.htm Date of access: 26 Dec. 2008.

MARTIN, J. 2007. The meaning of the 21st century. London: Eden Project Books.

PLUG, C., LOUW, D.A.P., GOUWS, L.A. \& MEYER, W.F. 2007. Verklarende en vertalende sielkundewoordeboek. Johannesburg: Heinemann.

PROCTER, P. 2002. Cambridge International Dictionary of English. Cambridge: Cambridge University Press.

REPUBLIC OF SOUTH AFRICA. 2003. National policy on religion and education. Government gazette, 459(25459).

RORTY, R. 2000. Fundamentally flawed. Civilization, 7(1):79, Feb./Mar.

RORTY, R. 2003. Religion in the public square: a reconsideration. Journal of religious ethics, 31(1):141-149.

RORTY, R. 2004. Philosophical convictions. The Nation, 14:53-55, Jun.

RSA

see REPUBLIC OF SOUTH AFRICA

SAMSOM, R.H. 1981. Om het hart van het onderwijs. Kampen: Kok.

SINCLAIR, J.M. 1999. Collin's Concise English Dictionary. Glasgow: HarperCollins.

SMOLLETT, S. 2002. Ontological status of universals. http://www.yellowpigs. net/philosophy/universals Date of access: 26 Dec. 2008.

STURM, J., GROENENDIJK, L., KRUITHOF, B. \& RENS, J.A. 1998. Educational pluralism - a historical study of so-called "pillarization" in the Netherlands, including a comparison with some developments in South African education. Comparative education, 34(3):281-297. 
THE PEW FORUM. The pew forum on religion and public life surveys. http://pewforum.org/docs/?DoclD=153\#about Date of access: 26 Dec. 2008.

UNITED NATIONS. 2000. Earth Charter. Place?

VAN DER WALT, B.J. 2007. Transforming power. Potchefstroom: Institute for Contemporary Christianity in Africa.

VAN DER WALT, J.L. 2009. Metaphorical bridgebuilding for promoting understanding and peaceful coexistence. HTS Theological Studies, 65(1), Art. \#299, 5 pages. DOI:10.4102/hts.v65i1.299.

VAN DER WALT, J.L. \& OOSTHUIZEN, I.J. 1998. A legal and philosophical perspective on the in loco parentis position of teachers. Koers, 63(1 \& 2):89-100.

VAN NIEKERK, A. 2005. Contingency and universality in the Habermas-Rorty debate. Acta academica supplementum, 2:21-41.

VILAR, C. 2005. Real international statistics on religion. http://www. Religionstatistics.net. Date of access: 2 Jan. 2009.

WILLIAMS, P. 2005. A high court history of church versus state. Case by case, it's a religious versus secular debate. US News 27 June. http://www.msnbc.msn.com/id/8256763/ Date of access: 13 Jan. 2008.

WOOLFENDEN. 2008. Review of Universals by Donald E. Brown. www.Ishkbooks.com Date of access: 26 Dec. 2008.

WORLD FACTBOOK. 2008. The 2008. https://www.cia.gov/library/publications/ the-world-factbook/print/as.html Date of access: 26 Dec. 2008.

\section{Key concepts:}

ethos

institutional identity

religion education

school

universal-particular problem

\section{Kernbegrippe:}

universeel-partikulier-probleem

etos

godsdiensonderwys

institusionele identiteit

skool 